\title{
Public Policy Pragmatism on Special Economic Zone in Tanjung Lesung, Pandeglang Regency
}

\author{
${ }^{1}$ DEDE SRI KARTINI, ${ }^{2}$ RAHMAN MULYAWAN, ${ }^{3}$ MURADI \\ ${ }^{123}$ Universitas Padjadjaran, Jalan Raya Bandung-Sumedang Km. 21 Jatinangor, Indonesia, \\ email: ${ }^{1}$ dedekartini@yahoo.com; ${ }^{2}$ rahmanmulyawan@yahoo.com; ${ }^{3}$ muradiclark@gmail.com
}

\begin{abstract}
The policy of Special Economic Zone (SEZ) in Tanjung Lesung has provided various special facilities to investors, such as tax breaks, business use rights, and building rights for 80 years. This research is discussing whether this is an ideal policy or only pragmatism. It is an attempt to discover and analyze whether the Special Economic Zone policy in Tanjung Lesung is an ideal policy that has met the public interest. Using qualitative methods, researchers conducted an interview with the government, Regional House of People's Representatives, and society. The results of this study indicate that Special Economic Zone policy is divided into three conditions: conditions that describe policy pragmatism such as ensuring fair competition among hotel and lodging business actors, respecting people who do not want to sell their land, both domestic and foreign investors have the same rights and obligations; conditions that do not describe policy pragmatism such as rules that cannot be applied; and conditions that describe half pragmatism such as formal tourism education aimed for vocational schools only.
\end{abstract}

Keywords: Public Policy, Pragmatism, Special Economic Zone

\section{Introduction}

Governments in various developing countries carry out various ways to improve people's welfare, including by issuing policies in the form of easy investment for both foreign and domestic investors to boost people's income so that it can reduce poverty. This was also done by the Indonesian government through the establishment of several regions to be Special Economic Zones (SEZ). This is a form of government response to improve welfare by using the concept of historical perspective modernization (Sztompka, 2011).

The Law No. 39 of 2009 concerning SEZ was then responded by the Government Regulation (PP) No. 26 of 2012 concerning Special Economic Zones in Tanjung Lesung. The PP can be used to further strengthen the role of this region as a tourism area. This Government Regulation was then responded by the Regional Development Planning Agency of Pandeglang Regency with an action plan of forming institutions consisting of the establishment of the SEZ Board, and establishment of SEZ Board Secretariat. The establishment of SEZ Administrator is an Action Plan for Delegation of Authority and Determination of SEZ Development Business Entities in Tanjung Lesung. In addition, the SEZ Administrator was formed by Regional Regulation No. 2 of 2014 which carries out the One Stop Service Function.

After being inaugurated in 2015 by President Joko Widodo, SEZ in Tanjung Lesung was facing policies that had not been in favor of public interest (Riant D. Nugroho, 2004), for example, competition in the field of lodging between hotels managed by investors with large capitals and homestays managed by local people with small capital. There are 13 legal rules governing SEZ without being accompanied by technical rules which confuse the field implementers on how to implement them. A rule of tax incentives is one of them that cannot be applied. Business entities being empowered are limited to the owners of homestays, so that there is progress in the SEZ of Tanjung Lesung. Education to face global challenges already exists, although it is only limited to the establishment of 
Tourism Vocational Schools. The privatization of State-Owned Enterprise does not yet exist since there is no State-Owned Enterprise that invests SEZ in Tanjung Lesung; subsidies are not on target and domestic investors have not received optimal attention. Whereas, good governance as an interaction between local government, investors, and the public is still waiting for the central government command. The only one thing that has been fulfilled in this SEZ policy is building the democratic skills.

Previous research on SEZ policy in Tanjung Lesung has not yet been found so that it becomes an element of novelty in this study. The research with a theme of policy similar to this one is by (Henckels, 2018) who discusses the public policy and investment, and (Pakdeenurit, 2014) who discusses SEZ in India. Henckels did a research on how far the law can give an exception to investment, with the meaning that there is a convenience for the coming investments, provided that it does not disturb the stability of a country. Pakdeenurit saw the failure of SEZ in India was due to the management errors. He identified that $60 \%$ of the countries that enforced the SEZ were successful because it was managed by private sector. This research is different from both Henckels and Pakdeenurit because it will not view the rules regarding investment or the failure of SEZ but will see the extent to which SEZ policies have succeeded in fulfilling the public interests.

The definition which states that policy is whatever a government chooses to do or not to do is no longer appropriate for the systematic analysis of public policy. The thing that must be prioritized is what the government does in accordance with the needs of the community (Adam A Anyabe, 2018). The researcher agrees with Anyabe's opinion, and this is parallel with what Ian Patrick Agustin stated, as quoted (Nugroho, 2004), that policies must be pragmatic, meaning that policies issued must meet public needs. This study wants to see the extent to which the Special Economic Zone policy in Tanjung Lesung have succeeded in meeting public needs by using the policy pragmatism theory by Ian Patrick Agustin.

When an area is intentionally opened for capital owners to carry out their economic activities and the capital investment is regulated, then the capitalization occurs. As said by (Saksosno, 2015): "Capitalist companies refer to disciplined labor and regulated capital investment." For researchers, today it is not only companies that capitalist, but the government can be capitalist too with a set of policies issued. Through policies, rural areas with traditional properties are transformed into investment land with a set of rules.

SEZ policy has brought social change to traditional communities in the region. This is because modern conditions that immediately bring the concept of development clearly affect human personality. The influence of modernity on humans is reflected through urbanism, industrialism, mobility, and mass communication (Sztompka, 2011). Judging from the policy typology, the SEZ policy is a procedural policy because it does not arise from the needs of the community but rather emphasizes on who will implement and how it is implemented (Agustino, 2008).

The government is indeed an institution and part of the political process, a place to choose what public policies to be made (Kraft \& Scott R. Furlong, 2007). Policies made are also influenced by various conditions, such as social and economic, government structures, local and national cultural norms, and others. This condition will then determine policy alternatives (Kraft \& Scott R. Furlong, 2007). Policy choices are part of the "way" to implement the chosen policy to solve problems or explore the benefits of the program (Siong \& Geraldine Chen, 2007). The making of policy has various objectives, including the goal of regulating and liberating and (Nugroho, 2015).

According to (Jayasuriya, 2006), a capitalist economic system that upholds the values of liberalism has one characteristic that is similar to the contemporary forms, namely in viewing a welfare-oriented government. One way to achieve prosperity is to bring in as many investors as possible by providing global facilities. For example, the right to use and the rights of business use in SEZ Tanjung Lesung are the same as SEZ in any country which has been applied for 80 years. This indicates that capitalization is in line with globalization.

The government, in general, cannot escape globalization which is usually inherent in capitalization, but the government can adapt and accept its effects because of three things: (a) In terms of the economy, global economic integration can be said to be "inefficient" in the way of setting limits for domestic politics but allowing openness for the global economy; (b) Globalization has caused 
an imbalance, but it also offers technological exchange needed by developing countries. It's the reason for globalization to be adapted in the country; (c) Globalization can strengthen or weaken state institutions depending on the size, power, and domestic political culture in which the country is involved (Keohane \& Donahue, 2000).

Jaysuria argues that a person's capability or ability can be a mediator and is the key to reconciliation between the liberal conception of individual autonomy and social commitment to equality. The ability and capability of the government in involving all existing stakeholders is the key to bringing together the interests of capital and broader public welfare. In essence, Kanishka Jaysuria wants to bring up "the third way" as an alternative thought to harmonize the market system (liberalism) with socialism that prioritizes shared prosperity.

According to Ian Patrick Agustin, the ideal policy he calls pragmatism in public policy means a policy model that uses the "profit-loss" ratio of a policy (Nugroho, 2004), as introduced in the cost and benefit analysis paradigm proposed by Boardman in (Nugroho, 2004). Every policy must take into account the profit and loss without ignoring the ethical element. According to Molan in Nugroho (2004), pragmatism is not synonymous with opportunism. Pragmatism is also not just practicalism. Pragmatism refers more to the necessity of each idea to refer to the consequences of its implementation. Pragmatism is closer to the setting theory goal, meaning that each action must refer to a goal. Pragmatism must be ethical and strategic. Ethical means that the pragmatic nature is intended for the public interest and not for the elite (Nugroho, 2004). According to him, the ideal policy has the following characteristics as mentioned in Table 1.

Table 1 Ideal and Deviant Policy Characteristics

\begin{tabular}{|c|c|c|}
\hline No & Ideal & Deviant \\
\hline 1 & $\begin{array}{l}\text { Ensuring a fair } \\
\text { competition }\end{array}$ & $\begin{array}{l}\text { Giving protection } \\
\text { and monopoly } \\
\text { without clear } \\
\text { boundaries }\end{array}$ \\
\hline 2 & Legal certainty & Legal bias \\
\hline 3 & Proportional tax & $\begin{array}{l}\text { Regional taxes that } \\
\text { absorb the ability of } \\
\text { the general public }\end{array}$ \\
\hline 4 & $\begin{array}{l}\text { Empowering } \\
\text { business entities }\end{array}$ & $\begin{array}{l}\text { Business entities on } \\
\text { sale }\end{array}$ \\
\hline
\end{tabular}

5 Education refers to Education global challenges uniformity

6 Building democratic Opening the path skills

7 Privatization in the form of distribution of ownership of State-Owned Enterprises to the domestic public fairly and evenly

8 Subsidies are proportional/in accordance with the desired subsidy targets

9 The same opportunity for investors to control domestic and global national productive investors to control economic assets national productive economic assets

10 Policies that guarantee the application of good governance principles in each organization

of democracy without any clear boundaries

Privatization of State-Owned Enterprises in the form of transferring monopolies from the state to the private sector or to foreign parties

Subsidies are without limits or total/extreme removal of subsidies

Prioritizing

Policies that give groups the discretionary right to implement good governance

Source: (Nugroho, 2004)

Pragmatism is not opportunism but has the ethical meaning as well as various meaning of policies. Policies can refer to actors, programs, formal authorities, and others (Turner \& David Hulme, 1997).

\section{Research Methodology}

This research uses qualitative method, which according to (Ritchie, 2014) is:
"A set of interpretative, material practices that make the world visible. These practices transform the world. They turn the world into a series of representatives, including field notes, interview, conversation, photographs, recording and memos. Qualitative researchers study things in their natural settings, attempting to make sense of interpret phenomenon in term of the meaning people bring to them."
The qualitative research method interprets empirical matters until they become clear. The interpretation is carried out through a set of activities which include field notes, interviews, conversations, photographs, and recordings. In this study, the researcher will interview the community, the Head of the SEZ Administrator's Office, the Head of Regional Development Planning 
Agency of Pandeglang District, the Head of Panimbang District, and the Head of Tanjung Jaya Village. The selected informants are in accordance with the characteristics of SEZ in Tanjung Lesung in addition to surrounding communities who have been there first, such as fishermen and the owner of the inn. The Head of Administrative Office that runs the SEZ managing the processes from licensing to investment enters the SEZ in Tanjung Lesung. The Head of Regional Development Planning Agency must adjust development planning in Pandeglang Regency with the presence of SEZ in Tanjung Lesung. Head of Panimbang Subdistrict, as the head of the foremost region where Tanjung Lesung is located, should have the knowledge of Tanjung Lesung development with all its the positive and negative impacts. Finally, the Head of Tanjung Jaya Village as a village directly adjacent to Tanjung Lesung SEZ. This village was the first to experience the direct impact of SEZ presence, both positive and negative.

This qualitative research has contextual function often called descriptive or exploratory. The main objective of this study is to investigate and interpret the social phenomena of experience that researchers must understand. The validity in this study includes: credibility (internal validity), transferability (external validity), dependability (reliability), and confirmability (objectivity) (Sugiyono, 2006). In addition, qualitative research is more flexible in determining the focus of research (Neuman, 2004).

The approval of Tanjung Lesung as a SEZ has brought new problems such as competition between owner of lodgings managed by the community and existing hotels in the region, government officials who have difficulties implementing SEZ rules, training for general public, narrow access to enter the beach for fishermen, and supporting infrastructure that has not yet existed in the SEZ Tanjung Lesung. From these problems, the question arises is: to what extent SEZ policies have fulfilled the public interest? The fulfilled or unfulfilled public interest will be confirmed by the theory of pragmatism in public.

\section{Results And Discussion}

In the Law No. 39/2009 concerning Special Economic Zones (SEZ), it is stated the meaning of Special Economic Zones as an area with certain limits in the legal territory of the Unitary State of the Republic of Indonesia which is determined by carrying out economic functions and obtaining certain facilities. Thus, each SEZ performs economic functions and special facilities provided by the Central Government, in which these special facilities do not exist elsewhere. This function of the economy and special facilities that differentiates districts with SEZs from districts without SEZ. In accordance with Government Regulation Number 26 of 2012, the SEZ in Tanjung Lesung is designated as the SEZ of Tourism Zone, an area designated for tourism business activities to support the implementation of entertainment and recreation, meetings, incentive trips and exhibitions, and related activities.

When the Central Government issues a policy, the regions inevitably have to follow it. Regarding this SEZ policy, it is a national policy that is implemented together by the Province and District. The SEZ is a central government program, so that the regional government of Pandeglang district cannot refuse it. Nevertheless, the Regional Government must prepare the community to be able to deal with the SEZ impacts by prioritizing local content. The program is planned since 2010 and will be ratified and implemented in 2012. It can be said that the SEZ in Tanjung Lesung is a trial program because the devices are not ready yet. In a big concept, the SEZ is designated as a Special Economic Zone aims to attract investment, in which there must be something special to offer. Unfortunately, until now there is nothing happened. Even though it has been declared operational, in fact, this SEZ has not done anything yet. SEZ failed to offer anything to investors until now although it has been there for 5 years. While what is known to the public, establishing special economic zones is similar to building industries.

Concerning the issuance of policies from both the Central and Regional governments, the explanation below will elaborate whether those policies are in accordance with the ideal policy characteristics that favor the public. Thus, the benefits of this research are the public, in which their importance or needs can or cannot be accommodated by the SEZ policy in Tanjung Lesung.

\section{Ensuring a Fair Competition}

According to the Tanjung Lesung master plan, there will be 12 buildings in operation. However, until now there is only 3 buildings 
exist. It turns out that the physical presence of SEZ with the infrastructure promised by the Central Government has an impact on the pattern of competition that occurs between the lodging businesses.

The construction of SEZ is predicted to invite massive investment, so that the government needs to guarantee fair competition. Competition needs to be anticipated between hotel owners, hotel owners and homestays, or competition between the homestays themselves. However, the feared competition does not occur because promised accesses such as toll roads, ports, and even airports have not yet built and cannot be predicted when it will be realized. This resulted in a hotel occupancy rate of only $35 \%$ on weekends. The SEZ in Tanjung Lesung, which is designated as a tourism area, relies on visits from domestic and foreign tourists to liven up the SEZ. To meet this need, hotels become a priority place. In accordance with Tanjung Lesung master plan, Tanjung Lesung Beach Hotel was built in conjunction with other beach tours, namely the Beach Club and Sailing Club. However, the master plan alone is not enough to operationalize SEZ and it needs other infrastructures to support. The provisions of national, provincial and district roads that lead to Tanjung Lesung will support the SEZ, in addition to toll roads, airports and reactivation of railroad transportation as National Strategic Projects.

With a hotel occupancy rate of only $10 \%$ and a maximum of $35 \%$ on weekends, this indicates that tourists are still reluctant to visit the SEZ in Tanjung Lesung. The longdistance factor excludes Tanjung Lesung as a place to visit on weekdays. In addition, the facilities promised in the construction of Serang-Panimbang toll road will only begin in 2019. These are the imbalances occur between the Central Government's policy on SEZ and real conditions in the field. Even P.T. Banten West Java Tourism Development Corporation which proposes SEZ this company and other companies are still waiting for toll road facilities from the Government.

Investors are still waiting, and the Head of the SEZ Administrative Office in Tanjung Lesung can only do a promotion. If the toll road already exists, then 11 Mou (Memorandum of Understanding) of investments that are currently in the SEZ will be realized. It was also strengthened by Yangto as a member of the Regional House of Representative of Commission IV in Pandeglang District, stating that the Regional House of Representatives supported the budgets needed for the region. For example, the Administrative Office submits various budgets, and the Regional House of Representatives regulates to actualize the budgets. Likewise, the Regional House of Representatives does the same thing to the road construction to the SEZ in Tanjung Lesung. Unfortunately, until now, there are no investors who actualize those projects in reality. Verbally, there are many who interested, but there has not been any investor yet who really did put his capital in. They are waiting for the toll road construction, airports, and others. At present, the presence of SEZ has not given a positive value to the community.

In addition to the $83.6 \mathrm{~km}$ SerangPanimbang toll road infrastructure, South Banten Airport, Panimbang, the acceleration of transportation, electricity and clean water infrastructure in the Tanjung Lesung area has also not been realized. The three infrastructures have become National Strategy Projects (NSP), but there are still obstacles to the realization. There are damages of national roads by $30 \%$, provincial roads by $12 \%$ with severely damaged, and district roads by $30 \%$. Another obstacle is the absence of type $\mathrm{C}$ terminals close to the SEZ in Tanjung Lesung and there is no Banten ring tourism tour/ bus transportation, other than PLN (National Electricity Company) that has not been willing to build a substation if there is no certainty of demand from investors. Despite the obstacles, there are also supporting factors such as the railroad that is ready to be reactivated.

\section{Legal Certainty}

There are 13 policy products regulate SEZ in Tanjung Lesung, which from the form of laws to regent regulations. Each policy product has an emphasis on what should be done to the SEZ in Tanjung Lesung as the region was officially opened in 2012 by President Jokowi. With no operational rules covering the SEZ, investment is hampered.

However, it turned out that the equipment provided by the central government for investment was not optimal. First, the SEZ constraints encountered in Tanjung Lesung occurred in all SEZ. Thus, the obstacles can be found from various sides: the investment side, the rules of the game, the mastery of the field, and the master plan. it is not wrong for the public to think this project goes very slow because the policies at the central level have 
not been completed, such as the concept of the device and everything needed. In contrast to abroad, the SEZ is ready to be operational with all the devices have been completed and the incentives for the rules of the game are all done.

\section{Proportional Tax}

Through Law No. 39 of 2009, the government provided conveniences to SEZ investors, such as deferring import duties, exempting excise tax, and no charge for Value Added Tax, Tax on Luxury Goods, and Import Income Tax. Every taxpayer who conducts business at SEZ is given incentives in the form of exemption or relief of regional taxes and regional levies. Besides that, the regional government can also provide other facilities if needed.

In addition to the above facilities, SEZ also has the convenience of obtaining land rights, as well as facilities and relief in the fields of business licensing, business activities, industry, trade, and immigration for foreign business people, as well as security facilities.

This convenience can also be legal because there are no derivative regulations, such as convenience in Land and Building Taxes, imported goods, and Income Taxes. This law also allows global investors to control national productive economic assets, for example the construction of hotels that take the area where fishermen usually get their fish for living. It appears there is a policy deviation if the researcher uses the policy theory.

\section{Empowering Business Entities}

While waiting for the accessibility to be built by central government, the local government, in this case, the SEZ Administrator Office in Tanjung Lesung has revived small-scale investments, such as homestays, restaurants, which are actually strategies to show at least (little) progress of SEZ in Tanjung Lesung, although there is risk of losses from business actors. This is a place where different interests of government and business met.

The feasibility of SEZ policy is low because it has not finished its accessibility yet. This situation is bad because it will be hard to attract investment without the airport and toll road (that have not built yet), while accessibility is the most sensitive thing for investors. Thus the strategy is, while waiting the accessibility, the Regional Government enliven the area first, hold a festival, prepare the community, and build the homestays. When all SEZs are ready and available, there will be no market competition between businesses in the SEZ area and buffer zone because both have their respective target markets. Government targeted the inside area for the upper middle class market, while buffer zone for the lower middle class market. In fact, many domestic tourists stay at homestays, while tourists from abroad stay in the region. The government hopes that in the end it can avoid the exclusivity of this SEZ. This synergy is maintained by the SEZ Administrative Office to avoid competition and have a partnership instead.

\section{Education that Refers to Global Chal- lenges}

Formal education that refers to the new global challenges is limited to the Vocational Tourism. The Regional House of People's Representatives manages it by asking the government to conduct human resources training, such as tourism awareness training. This training is intended first for homestay owners.

The clash between religious local culture and the arrival of foreign tourists must be anticipated. While formal tourism education in accordance with the needs of SEZ does not exist yet, the Regional Government takes the initiative to conduct tourism awareness training, such as training for homestay owners. The training is conducted to provide education for the people who can support them in facing the potential and risks arise from SEZ policy, as it was stated below:

\footnotetext{
"As far as I am concerned, the presence of a homestay will be initiated from BWJ (Banten West Java). Offer 'hospitality' to guests, and people here can serve guests. If the hotel is full, you can come here. Let's help each other out."
}

But after being further observed and examined, the training seemed to be merely a formality. It was not meant for a long term. Findings from the field showed that SEZ policies can bring benefits to the welfare of the community with the condition that both central and regional governments through relevant agencies able to design long-term sustainable training programs. This training becomes important to improve the quality of human resources in Tanjung Lesung, so that they can actively participate and utilize the potential brought by SEZ policies and not only be observers. On the other hand, it will 
DEDE SRI KARTINI, et al. Public Policy Pragmatism on Special Economic Zone in Tanjung Lesung, Pandeglang...

be more effective for the SEZ policy if human resources in the region are already qualified.

\section{Building Democratic Skills}

In addition to formal juridical methods, which will later cover the relations between workers and company owners, the Regional Government does not mention the rights people who currently inhabit the land of SEZ in Tanjung Lesung, that is Kampung Bodur for exact, even though the land is actually a place of state workers as stated by Hadi, "Now for the land problem, there is no solution yet. I have with the BWJ leaders (Banten West Java) several times to find a solution that can accommodate the interests of all of them. "

This shows that the Regional Government, namely the Regional House people's representatives and Regent, respects the rights of people of Bodur village who have been hereditary in the area which is now a SEZ. In addition, the Regional House people's representative also considers that there is still a lot of land that has not been utilized by PT. BWJ.

This SEZ policy then educates the people to be aware of democracy. The values of organizational freedom and freedom of opinion, for example, appear as a means of society in the process of maturing and understanding the democracy itself. In facing this SEZ policy, in the end, it forces the people of Tanjung Lesung to realize their rights as citizens in the scope of democracy. When there are polemics and interests that they perceive as not in accordance with the needs and welfare of the people, they dare to express their opinions by holding a demonstration to the government.

In addition, the public also realizes that to aggregate their interests and get accommodated by the government as policymakers of SEZ, they need an organization with the same vision and mission to protect the interests of the community and not to be eroded by the existing capitalization. Based on this reason, there are already many community organizations and associations in Tanjung Lesung region which often become the means of the community to express their aspirations. One example is the aspirations of Kiayi associations who view this SEZ policy as having a bad impact when it is not guarded by strong aspects of morality. This was stated by cleric Yana as a community leader:

"Besides that, there are also external parties, namely groups of Kiai who are not willing to take part. Is this study a must? The state should clearly define $r$ what it is for. Is it for the welfare of the community or not? What are the aspects for? Is it only for foreign investors? We can also understand the wishes of the Kiai. Maybe local wisdom is lost, right? We don't want Pandeglang like the second Bali, right? "

Apart from the community side, maturity in democracy also took place at the government level. The aspirations and interests of the people who are often expressed through demonstrations, on the basis of awareness of rights as democratic citizens, also force the government to respond appropriately to those aspirations.

From these findings, it can be seen that the SEZ policy in Tanjung Lesung has a good impact on the democratic learning of the people. Regardless of the interests and mounts that accompany the expression of opinion and organization, or the stuttering and scepticism of local government in responding to the expressions made by the community, we can all see it as a process of maturing democracy.

\section{Privatization in the Form of Dis- tribution of Ownership of State Owned Enterprises to Domestic Public in a Fair and Equitable Way}

There has not been a domination of Ownership of State-Owned Enterprises in SEZ Tanjung Lesung so far since only PT Telkom will do the investment in SEZs. It is because other investors are still waiting so that there is no spread of ownership of State-Owned Enterprises to the domestic public fairly and evenly. Other State Owned Enterprises will conduct their activities when there is funding from the Central Government, such as the construction of toll roads, railways, and airports. Toll roads and airports are included in the National Strategic Project. However, until now there has been no State Owned Enterprises working on the National Strategic Project (NSP).

\section{Subsidies are Proportional/ In Accordance with the Desired Sub- sidy Target}

The presence of SEZ in Tanjung Lesung has an impact on the provision of subsidies from the government to the people in the area, especially fishermen. However, results of this study indicate that there is still an inaccuracy or even the absence of these subsidies to the public, as revealed below:

"From the Government, there may be 
continuous funds, but for certain people and not for the fishermen. If our group just made it yesterday, it because there was help from floating cages. That makes it hurry. The official person is straight away. "

The ineffectiveness of subsidies provided by the government to the people in the Tanjung Lesung region is also revealed:

"We must also have a fisherman card as the term card for the programs. This is a card for the real fisherman with insurance in it. If you are a teacher, you can not possibly have a fisherman card. (laugh). But are no help for our facilities. Madam!"

The existence of subsidies that are not aligned precisely with the government's target, according to additional information stated by Anang, can occur because of the dishonesty occurs among members of the cooperative. Anang added,

"I heard a lot of people asked the cooperative people. There are many, but only certain people can. They took benefits only for themselves, and so did the government. The personal identity card is collected, but the follow-up doesn't exist. Everything is here. Banten has the most help. But this assistance does not reach the fishermen and goes to certain people, the bosses, the rich ones. "

\section{The Same Opportunity for Domestic and Global Investors to Control Na- tionalProductive Economic Assets}

Until now, there are 8 (eight) investors who will invest their capital, but they are still waiting for infrastructure development from the Government. The following are the names of investors who will invest in the SEZ Tanjung Lesung in Table 2.

The table above shows there are 5 foreign investors and 3 domestic investors, indicating that domestic and global investors have the same opportunity to control national production assets. Although this area is free for anyone who wants to invest in SEZ Tanjung Lesung, there are rules to obey, for example, no permit for casino. There are some businesses that fully owned by foreigners and some that partially owned by foreigners. Joyce Irmawati states:

Table 2

Investors in SEZ Tanjung Lesung

\begin{tabular}{|c|c|c|}
\hline Company name & Project name & Progress and Status \\
\hline $\begin{array}{l}\text { Pigeon Barries Ltd, UK } \\
\text { Area: } 5 \text { ha }\end{array}$ & Hunting Lodge \& Shooting Range & Construction Phase (Ongoing) \\
\hline President University & $\begin{array}{l}\text { Center for National Maritime } \\
\text { Culture studies }\end{array}$ & $\begin{array}{l}\text { Phase of Pre-Feasibility Study } \\
\text { (ToR) }\end{array}$ \\
\hline $\begin{array}{l}\text { PT. Telekomunikasi Indonesia Tbk } \\
\text { Area: } 1500 \text { ha }\end{array}$ & Tanjung LesungDdigital World & $\begin{array}{l}\text { e-ticketing and fiber optic } \\
\text { installation, as well as installing } \\
\text { wifi in the area } \\
\text { (On going) }\end{array}$ \\
\hline $\begin{array}{l}\text { PT. Pelindo II } \\
\text { Area: } 100 \text { ha }\end{array}$ & Cruise and Terminal Marine & $\begin{array}{l}\text { The preparation phase of the } \\
\text { Feasibility Study. Masterplan } \\
\text { with consultants of: } \\
\text { 1. Royal Haskening } \\
\text { 2. BMT Asia Pacific } \\
\text { 3. AECOM } \\
\text { 4. Roland Berger }\end{array}$ \\
\hline $\begin{array}{l}\text { Daewoo Development } \\
\text { Area: } 1500 \text { ha }\end{array}$ & Construction and Infrastructure & $\begin{array}{l}\text { Phase Cooperation Agreement } \\
\text { (PCA) } \\
\text { (On going) }\end{array}$ \\
\hline $\begin{array}{l}\text { Korea Teddy Bear Association } \\
\text { Area: } 1 \text { ha }\end{array}$ & Theme Park & $\begin{array}{l}\text { Phase Cooperation Agreement } \\
\text { (PCA) } \\
\text { (On going) }\end{array}$ \\
\hline $\begin{array}{l}\text { Kedutaan Besar Mongolia } \\
\text { Area: } 1 \text { ha }\end{array}$ & Theme Park & $\begin{array}{l}\text { Phase Cooperation Agreement } \\
\text { (PCA) } \\
\text { (On going) }\end{array}$ \\
\hline $\begin{array}{l}\text { Middle East } \\
\text { Area: } 1500 \text { ha }\end{array}$ & $\begin{array}{l}\text { Infrastructure and Joint } \\
\text { Development }\end{array}$ & $\begin{array}{l}\text { Phase Cooperation Agreement } \\
\text { (PCA) } \\
\text { (On going) }\end{array}$ \\
\hline
\end{tabular}




\begin{abstract}
"PP other regulations, and later on the BKPM, also regulate this. In addition to the limited business fields, there are foreign ownership permitted up to $100 \%$. There are some fields that may not be full, a maximum of $50 \%$ if I am not wrong. And also the ownership of foreign investors may have a place to live. Ownership rights and use rights valid up to 80 years. It is home footprint. Why is it enforced? Because almost all SEZ in the world carries out the same strategy"
\end{abstract}

Ownership Rights and Use Rights have a time limit up to 80 years according to the rule of SEZ throughout the world. If the SEZ in Tanjung Lesung does not apply the same thing, then it will not be good for the competition with SEZ in other countries such as Malaysia, Korea, and Singapore. They offer the same things just like SEZ in Tanjung Lesung. It is the only reason for the SEZ in Tanjung Lesung to deal with this strategy. However, Indonesia must offer different things. If foreign ownership is the same as local, then the SEZ in Tanjung Lesung must have minimized the social impact.

In order to support the existence of free from social conflicts-SEZ in Tanjung Lesung, the Regional House Representative plans to propose a port construction. First, the port will become the national fish production, so that there will be more of fishing boats found and stay in the port. Second, ports for the transportation of goods and people to Jakarta can pass Panimbang region. Regional House Representative encourages this development to become an alternative to congestion in the port of Merak. However, the convenience given by the government to foreign investors withvery large capital is not given to the community and small traders in the SEZ. In other words, in terms of development, inequality does occur. Investors with large capital are promised infrastructure development that consumes large amounts of money, while residents of the community around the SEZ experiences difficulties in obtaining adequate infrastructure.

\section{Policies that Guarantee the Applica- tion of Good Governance Principles in Every Organization}

The research results regarding the application of good governance principles show that Indonesia is still in the stage of achieving an ideal SEZ policy compared to other countries which have already implemented this SEZ policy well. Indicator of readiness and ongoing evaluation are needed to achieve the goal above. Field findings indicate that preparation and evaluation continue to be carried out routinely, for example, economic evaluation by the Coordinating Minister every 6 months and the Administrative Office conducts evaluations every 3 months. This is done in order to manage the obstacles arisen in SEZ policies such as investors, infrastructure, and other supporting factors which are still unavailable. This evaluation is carried out involving all existing stakeholders to find solutions and ways to resolve and deal with the obstacles arisen. This means that the government tries to accommodate all opinions and interests not only from the main stakeholder and intermediary but also other stakeholders of private sector investors and local community. Of course, what is done by the government in guarding the SEZ policy in the Tanjung Lesung can be seen as one of the applications of good governance principles, although in some cases the government still prioritizes the interests and opinions of investors than the society.

\section{Conclusion}

There are 3 conditions towards policy: conditions that have described policy pragmatism, conditions that do not describe policy pragmatism, and conditions that half illustrate policy pragmatism. Conditions that describe policy pragmatism can be seen from good competition without any disturbance in lodging business of both outside and inside the SEZ. The existence of SEZ policy has built public awareness to defend their rights. Respecting a group of people who do not want to sell their land is in line with building democratic skills in the community and managing the SEZ. Existing business entities are empowered by training home business groups, so that they have the ability to welcome and do the interaction with tourists. Both domestic and foreign investors have the same rights in accordance with SEZ rules such as Business Use Rights and Use Rights for 80 years, tax facilities, but are not allowed to run prohibited businesses such as casino.

The condition that does not describe policy pragmatism is proportional legal and tax certainty, which normatively cannot be implemented because there are no technical instructions. Likewise, the distribution of ownership of State-Owned Enterprises to the domestic public in a fair and equitable manner does not yet exist with regard to the State-Owned Enterprises that will invest, namely PT. Telkom and PLN are still awaiting 
requests from investors. A half-pragmatism policy condition can be seen from formal education that refers to new global challenges responded by establishing Tourism Vocational Schools to provide qualified workers in SEZ. The establishment of SEZ encourages the Regional Government to provide subsidies for fishermen, but these subsidies are given discriminatively and not in accordance with the needs of fishermen. Good governance which is characterized by balanced relations between the government, the private sector, and the community has not been realized because the government sometimes tend to prioritize the interests of investors only.

\section{References}

Anyabe, A. A. (2018). An Overview of Approaches to The Study of Public Policy. Journal of Social Science and Humanities, 13(1), 1-15.

Agustino, L. (2008). Dasar-Dasar Kebijakan. Bandung: Alfabeta.

Henckels, C. (2018). Should Investment Treaties Contain Public Policy Exception?. Boston College Law Review, 59(8), 2825-2844.

Ritchie, J. (2014). Qualitative Research Practice (2nd ed.). London: Sage Publication.

Jayasuriya, K. (2006). State Craft, Welfare and The Politics of Inclusion. In J. S. Nye \& J. D. Donahue (Eds.), Governance In A Globalizing World. New York: Brooking Institution Press.
Keohane, R. O., \& Donahue, J. D. (2000). Governance In A Globalizing World (J. S. Nye \& J. D. Donahue, Eds.). Washington DC: Brooking Institution Press.

Kraft, M. E., \& Scott R. Furlong. (2007). Public Policy : Politics, Analysis, and Alternatives (3rd ed.). Washington DC: Sage.

Neuman, L. W. (2004). Social Research Methods : Qualitative and Quantitative Approaches. London: Allyn and Bacon.

Pakdeenurit. (2014). Special Economic Zone: Facts, Roles, and Opportunities of Investment. Proceeding of MultiConference of Engineers and Computer Scientists. Hongkong.

Nugroho, R.(2004). Kebijakan Publik Formulasi, Implementasi dan Evaluasi. Jakarta: PT. Gramedia.

Nugroho, R. (2015). Kebijakan Publik Di Negara-Negara Berkembang. Yogyakarta: Pustaka Pelajar.

Saksosno, I. K. (2015). Bahaya Kapitalisme. Jakarta: Ampera Utama.

Siong, N. B., \& Geraldine Chen. (2007). Dynamic Governance: Embedding Culture, Capabilities and Change in Singapore. Singapore: World Scientific Publishing Co. Pte. Ltd.

Sugiyono. (2006). Metode Penelitian Kuantitatif Kualitatif Dan R\&D. Bandung: Alfabeta.

Sztompka, P. (2011). Sosiologi Perubahan Sosial. Jakarta: Prenada Media Group.

Turner, M., \& David Hulme. (1997). Governance, Administration and Development : Making The State Work. New York: Palgrave. 